\title{
ANALISIS KEPUASAN KONSUMEN DALAM MENGGUNAKAN SEPEDA MOTOR YAMAHA VIXION DI KECAMATAN BANGKINANG KOTA, KABUPATEN KAMPAR, RIAU
}

\author{
Suryalena $^{1)}$ Sri Zuliarni ${ }^{2)}$ \\ 1) Program Studi Ilmu Administrasi Bisnis, Universitas Riau, email: suryalena@ymail.com \\ 1) Program Studi Ilmu Administrasi Bisnis, Universitas Riau, email: srizuliarni.ur@gmail.com
}

\begin{abstract}
Abstrak
Penelitian ini bertujuan untuk menganalisis kepuasan konsumen dalam menggunakan sepeda motor Yamaha Vixion di Kecamatan Bangkinang Kota., Kabupaten Kampar, Riau. Metode pengumpulan data yang digunakan adalah melalaui questionnaire dan sebagai responden adalah seluruh konsumen yang aktif pada Yamaha Vixion Club (YVC) Chapter Bangkinang sebanyak 30 orang. Analisis data menggunakan metode deskriptif dan kuantitatif dengan pendekatan Kano. Penelitian ini menggunakan variabel kepuasan konsumen dengan 5 dimensi yaitu, kualitas produk, harga, kualitas jasa, emosional serta biaya atau kemudahan. Berdasarkan tanggapan responden bahwa kualitas produk memiliki fungsi linear dengan tingkat kepuasan konsumen. Berbeda dengan harga, bahwa konsumen menjadi tidak puas dengan penetapan harga yang rendah, namun apabila penetapan harga ditingkatkan tidak pula dapat menyebabkan kepuasan konsumen meningkat. Sementara kualitas jasa dan emosional adalah dimensi kepuasan konsumen kejutan (attracive). Artinya, kualitas jasa dan emosional sangat menyenangkan hati konsumen. Karena dianggap sebagai value added atau bonus, sehingga rendahnya pelaksanaan kualitas jasa dan emosional tidak menyebabkan konsumen tidak puas. Sedangkan, biaya atau kemudahan merupakan dimensi yang tidak menghasilkan kepuasan maupun ketidakpuasan konsumen.
\end{abstract}

Kata kunci: kepuasan konsumen, pendekatan kano, kualitas produk, harga, kualitas jasa, emosional, biaya atau kemudahan, yamaha vixion 


\section{PENDAHULUAN}

Era bisnis saat ini disebut sebagai era of choice, dimana konsumen dihadapkan pada banyak pilihan produk (barang dan jasa) di pasaran. Pada dasarnya semakin banyaknya pilihan produk yang dijual di pasar, maka semakin banyak pula pilihan bagi konsumen untuk dapat memilih produk yang sesuai dengan harapannya. Sehingga konsekuensi dari kondisi tersebut adalah konsumen menjadi lebih cermat dan pintar dalam menghadapi setiap produk yang diluncurkan di pasar.

Pebisnis terus menjalankan strategi pemasaran agar produknya tetap dapat diterima di pasar. Sehingga banyak bisnis menyadari adanya pergeseran orientasi bisnis/ perusahaan, dimana keuntungan finansial bukan lagi menjadi orientasi utama perusahaan. Namun lebih penting dari itu, bahwa orientasi utama sekaligus jangka panjang perusahaan adalah kepuasan konsumennya, karena konsumenlah alasan perusahaan terus dan tetap ada beroperasi.

Seperti yang dikemukakan oleh Kotler (2002) ada beberapa metode dalam mengukur kepuasan konsumen, antara lain:

1. Sistem keluhan dan saran

2. Survey kepuasan pelanggan

3. Belanja siluman

4. Analisis kehilangan pelanggan
Setiap bisnis saat ini biasanya membentuk suatu komunitas yang saling menginformasikan dan membuat individu sadar akan suatu merek tertentu. Untuk itu sangat diperlukan komunitas guna menarik perhatian dan mempertahankan konsumen. Dengan adanya komunitas akan membantu perusahaan sebagai perlindungan serangan persaingan. Dalam pengembangan sebuah merek, komunitas sangat berpengaruh terhadap strategi pengembangan merek tersebut.

Perkembangan industri otomotif di Indonesia membuat tingkat persaingannya semakin ketat, khususnya pada produk sepeda motor. Semakin beraneka ragam merek dan jenis sepeda motor yang ada, sehingga konsumen lebih selektif dalam memilih sepeda motor yang akan dibeli. Konsumen juga mepertimbangkan berapa biaya yang dikeluarkan untuk suatu merek tertentu. Sering kali suatu merek sepeda motor memiliki kesamaan bentuk dan kegunaan dengan merek lain sehingga konsumen sulit untuk membedakannya.

Persaingan terus terjadi antar sesama dealer resmi Yamaha yang berada di Kec. Bangkinang Kota, dimana perusahaan tersebut saling berkompetisi dalam penjualan sepeda motor untuk mempertahankan konsumen. Data realisasi penjualan sepeda motor merek Yamaha pada ketiga penjualan tersebut seperti dirincikan pada tabel 1 berikut.

Tabel .1. Daftar Dealer Resmi Yamaha di Kec. Bangkinang Kota

\begin{tabular}{|c|c|c|c|c|c|c|c|}
\hline \multirow{2}{*}{ No. } & \multirow{2}{*}{ Nama Dealer } & \multirow{2}{*}{ Alamat } & \multicolumn{5}{|c|}{ Realisasi Penjualan (Unit) } \\
\hline & & & 2009 & 2010 & 2011 & 2012 & 2013 \\
\hline 1. & $\begin{array}{l}\text { CV. Mahkota Motor } \\
\text { Bangkinang }\end{array}$ & $\begin{array}{l}\text { Jl. Prof. M. Yamin } \\
\text { Bangkinang, No. } 150\end{array}$ & 3.280 & 3.210 & 2.819 & 2.030 & 1.715 \\
\hline 2. & $\begin{array}{l}\text { PT. Yamaha Alfa } \\
\text { Scorpii }\end{array}$ & $\begin{array}{l}\text { Jl. Raya Pekanbaru - } \\
\text { Bangkinang }\end{array}$ & - & - & - & - & $\begin{array}{l}2.820 \\
(24 \text { juli } \\
2012-30 \\
\text { Des } \\
2013)\end{array}$ \\
\hline 3. & CV. Tri Star Kencana & $\begin{array}{l}\text { Jl. Prof. M. Yamin, } \\
\text { SH. No. } 91\end{array}$ & 3.960 & 4.140 & 3.960 & 2.040 & 1.800 \\
\hline
\end{tabular}

Sumber: CV. Tri Star Kencana Bangkinan, 2015

Dari tabel I1 tersebut dapat kita lihat bahwa CV. Tri Star Kencana selalu unggul dalam penjualan tiap tahunnya. Sampai dengan tahun 2012 di Bangkinang Kota, CV. Tri Star Kencana harus bersaing dengan CV. Mahkota Motor, namun masih lebih unggul dalam tiap penjualannya. Tetapi pada pertengahan tahun 2012 CV. Tri Star Kencana mendapatkan pesaing 
Suryalena \& Sri, Analisis Kepuasan Konsumer

baru yaitu PT. Yamaha Alfa Scorpii. Sejak tahun itu pula CV. Tri Star Kencana mengalami penurunan dalam penjualannya.

Berdasarkan uraian sebelumnya, maka penulis tertarik untuk melakukan penelitian mendalam dengan judul "Analisis Kepuasan Konsumen Menggunakan Sepeda Motor Yamaha Vixion di Kecamatan Bangkinang Kota, Kabupaten Kampar, Riau dengan Pendekatan Kano".

\section{KAJIAN TEORI}

\section{Lingkungan Kompetitif}

Porter (1980) memperkenalkan suatu model yang menggambarkan adanya lima kekuatan dalam lingkungan industri, dimana dinamika dari kelimanya menentukan intensitas persaingan, dan yang kemudian sangat berpengaruh pada perusahaan terutama pada profitability 'kemampuan menghasilkan laba' (lihat pada gambar II.1 berikut). Di Indonesia, ada kekuatan kompetitif ke enam, yaitu pemerintah, terutama di dekade 1980-an dan 1990-an melalui kekuatan tawarnya baik berupa keputusan kebijakan maupun melalui kegiatan BUMN.

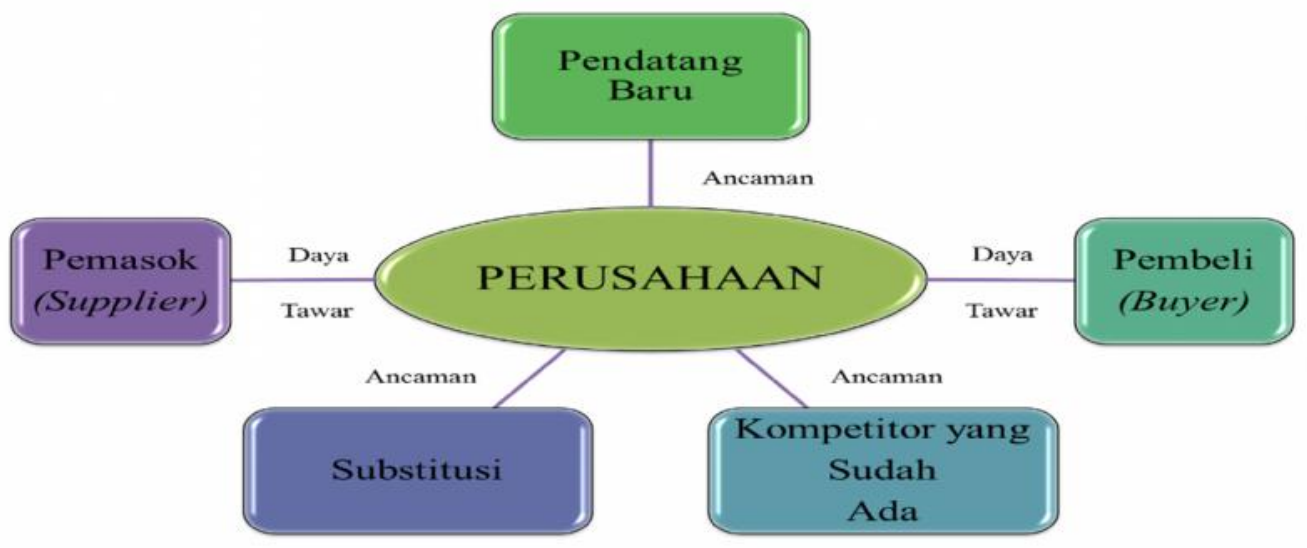

Gambar 1: Model Lima Kekuatan Kompetitif Sumber: (Porter:1980)

Dapat dilihat pada model diatas, bahwa pembeli (buyer, customer) memiliki kedudukan sebagai salah satu kekuatan kompetitif melalui daya tawarnya (bargaining power). Perusahaan yang gagal memahami kebutuhan, keinginan, selera, dan proses keputusan beli konsumen akan mengalami kegagalan dalam pemasaran dan penjualannya, sehingga akan gagal juga dalam kinerja keseluruhannya (Cravens, 2000). Sementara, perusahaan yang melakukan sebaliknya, yaitu memahami kebutuhan, keinginan, selera, dan proses keputusan beli konsumennya disebut customer-driven organization. Artinya, organisasi yang digerakkan oleh pemahaman terhadap pelanggan.

\section{Kepuasan Konsumen}

\section{a. Definisi}

Definisi kepuasan menurut Kotler (2002) adalah perasaan senang atau kecewa seseorang yang berasal dari perbandingan antara kesannya terhadap kinerja (atau hasil) suatu prodsuk dan harapan-harapannya. Menurut Tjiptono (2002) kepuasan konsumen merupakan evaluasi purna beli dimana alternatif yang dipilih sekurangkurangnya memberikan hasil (outcome) yang sama atau melampaui harapannya.

Dari kedua definisi diatas dapat ditarik kesimpulan bahwa pada dasarnya pengertian kepuasan pelanggan mencakup perbedaan antara harapan dan hasil yang dirasakan. Apabila disusun dalam sebuah bagan maka akan didapatkan sebuah model tentang kepuasan pelanggan sebagai berikut: 
Journal of Applied Business Administration Vol 1, No 1, Maret 2017, hlm. 122-138

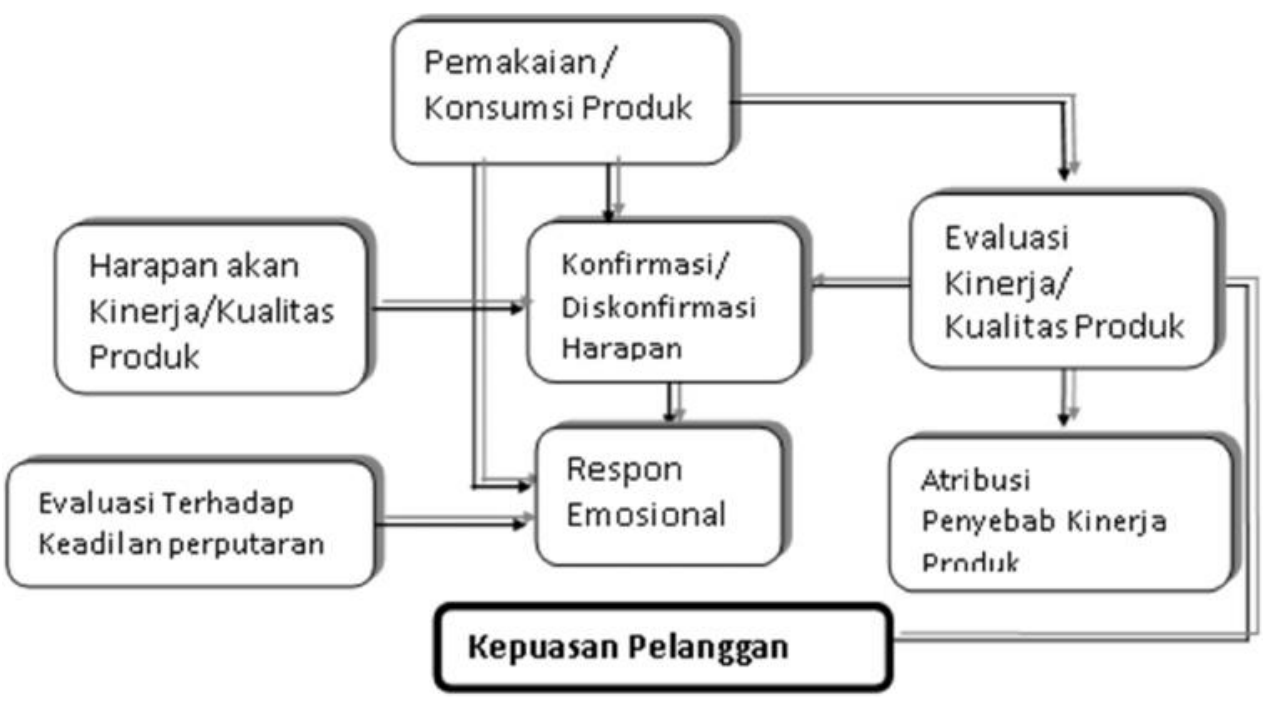

Gambar 2. Model Kepuasan Pelanggan

Sumber : Tjiptono (2002)

Pelanggan yang tidak puas akan segera meninggalkan produk yang tidak memuaskannya dan mudah untuk berubah pikiran pindah ke produk lain apabila mendapat penawaran produk yang lebih baik dari pesaing. Mereka yang amat puas akan lebih sukar untuk berubah pikiran ke produk pesaing, sebab kepuasan yang tinggi/ kelekatan emosional terhadap suatu merk akan menimbulkan preferensi rasional saja, akan tetapi bisa menimbulkan kesetiaan yang tinggi atau kesetiaan akan merk tertentu (brandl loyality).

Ciri-ciri pelanggan yang puas menurut Kotler (2002) adalah:

1) Menjadi lebih setia atau menjadi pelanggan yang loyal

2) Membeli lebih banyak jika perusahaan memperkenalkan produk baru mnyempurnakan produk yang ada.

3) Memberi komentar yang menguntungkan tentang produk dan perusahaan.

4) Kurang memperhatikan: produk, iklan, pesaing, kurang sensitif pada harga.

5) Memberikan gagasan atau ide kepada perusahaan.

6) Membutuhkan biaya pelayanan yang lebih kecil dari pada biaya pelanggan baru, Karena transaksi menjadi rutin.
7) Sedangkan pelanggan yang tidak puas akan melakukan berbagai tindakan seperti: pasif, tidak melakukan tindakan apapun.

8) Mengajukan keluhan dalam berbagai bentuk kepada perusahaan.

9) Melakukan aksi melalui puhak ketiga, misalnya kelompok advokasi, pelanggan, konsumen atau wakil dari pemerintah, hukum dan pengadilan.

10) Meninggalkan pemasok dan menghalanghalangi orang lain untuk menggunakan jasa (mengajukan hal-hal yang negatif perusahaan).

\section{b. Dimensi Kepuasan Konsumen}

Faktor-faktor pendorong kepuasan kepada pelanggan menurut Irawan (2007) adalah sebagai berikut :

1) Kualitas Produk

Pelanggan akan merasa puas setelah membeli dan menggunakan produk tersebut yang memiliki kualitas produk baik.

2) Harga

Biasanya harga murah adalah sumber kepuasan yang penting. Akan tetapi biasanya faktor harga bukan menjadi 
Suryalena \& Sri, Analisis Kepuasan Konsumer

jaminan suatu produk memiliki kualitas yang baik.

3) Kualitas Jasa

Pelanggan merasa puas apabila mereka memperoleh jasa yang baik atau sesuai dengan yang diharapkan dari pegawai maupun karyawan perusahaan.

4) Emosional

Kepuasannya bukan karena kualitas produk, tetapi harga diri atau nilai sosial yang menjadikan pelanggan puas terhadap merek produk tertentu.

5) Biaya atau kemudahan untuk mendapatkan produk atau jasa

Kenyamanan dan efisien dalam mendapatkan suatu produk atau jasa serta mudah mendapatkan jasa produk memberikan nilai tersendiri bagi kepuasan pelanggan.

\section{c. Pengukuran Kepuasan Konsumen}

Menurut Kotler (2002) ada beberapa metode dalam mengukur kepuasan pelanggan, antara lain:

1) Sistem keluhan dan saran

2) Survey kepuasan pelanggan

3) Belanja siluman

4) Analisis kehilangan pelanggan

Untuk lebih jelasnya di bawah ini disajikan cara-cara pelaksanaan metode-metode tersebut yang dijelaskan pada tabel 2 :

Tabel 2. Metode Pengukuran Kepuasan Pelanggan

\begin{tabular}{|l|l|}
\hline \multicolumn{1}{|c|}{ Metode } & \multicolumn{2}{|c|}{ Cara-cara Pelaksanaan } \\
\hline $\begin{array}{l}\text { Sistem } \\
\text { Keluhan } \\
\text { dan Saran }\end{array}$ & $\begin{array}{l}\text { Perusahaan memberikan formulir } \\
\text { untuk diisi pelanggan mengenai } \\
\text { keluhan-keluhan dan saran-saran dari } \\
\text { pelanggan untuk perusahaan }\end{array}$ \\
\hline
\end{tabular}

\begin{tabular}{|c|c|}
\hline $\begin{array}{l}\text { Survei } \\
\text { Kepuasaan } \\
\text { Pelanggan }\end{array}$ & $\begin{array}{l}\text { Penelitian langsung di lapangan yaitu } \\
\text { dengan memberikan daftan } \\
\text { pertanyaan atau juga bisa dengan } \\
\text { menelepon pelanggan-pelanggan } \\
\text { sebagai sample acak dengan } \\
\text { pertanyaan apakah mereka sangat } \\
\text { puas, kurang puas atau amat tidak } \\
\text { puas dengan berbagai aspek kinerja } \\
\text { perusahaan. }\end{array}$ \\
\hline & $\begin{array}{l}\text { Perusahaan dapat membayar orang- } \\
\text { orang untuk bertindak sebagai } \\
\text { pembeli potensial untuk melaporkan } \\
\text { temuan-temuan mereka tentang } \\
\text { kekuatan dan kelemahan yang } \\
\text { mereka alami dalam membeli produk } \\
\text { perusahaan dari produk pesaing. }\end{array}$ \\
\hline $\begin{array}{l}\text { Analisa } \\
\text { Kehilangan } \\
\text { Pelanggan }\end{array}$ & $\begin{array}{l}\text { Perusahaan harus menghubungi para } \\
\text { pelanggan yang berhenti membeli } \\
\text { atau berganti ke pemasok lainnya, } \\
\text { untuk mengetahiu penyebabnya. }\end{array}$ \\
\hline
\end{tabular}

Sumber : Kotler, 2002

Selain metode survey yag merupakan metoda yang paling banyak digunakan dari metode-metode pengukuran kepuasan konsumen seperti yang telah dijabarkan di atas, metode terbaru dalam penerapannya pada pengukuran kepuasan konsumen adalah model Kano. Model Kano sebenarnya telah ada sejak lama. Namun, penerapannya baru-baru ini menjadi acuan baru untuk mengetahui lebih dalam tentang hal-hal yang mempengaruhi kepuasan konsumen.

\section{d. Model Kano}

Model Kano merupakan suatu model yang bertujuan mengkategorikan atribut-atribut dari produk atau jasa berdasarkan seberapa baik produk/jasa tersebut mampu memuaskan kebutuhan pelanggan. Model ini dikembangkan oleh Profesor Noriaki Kano (Kano, 1995) dari Universitas Tokyo (dalam Fajar, 2011). 


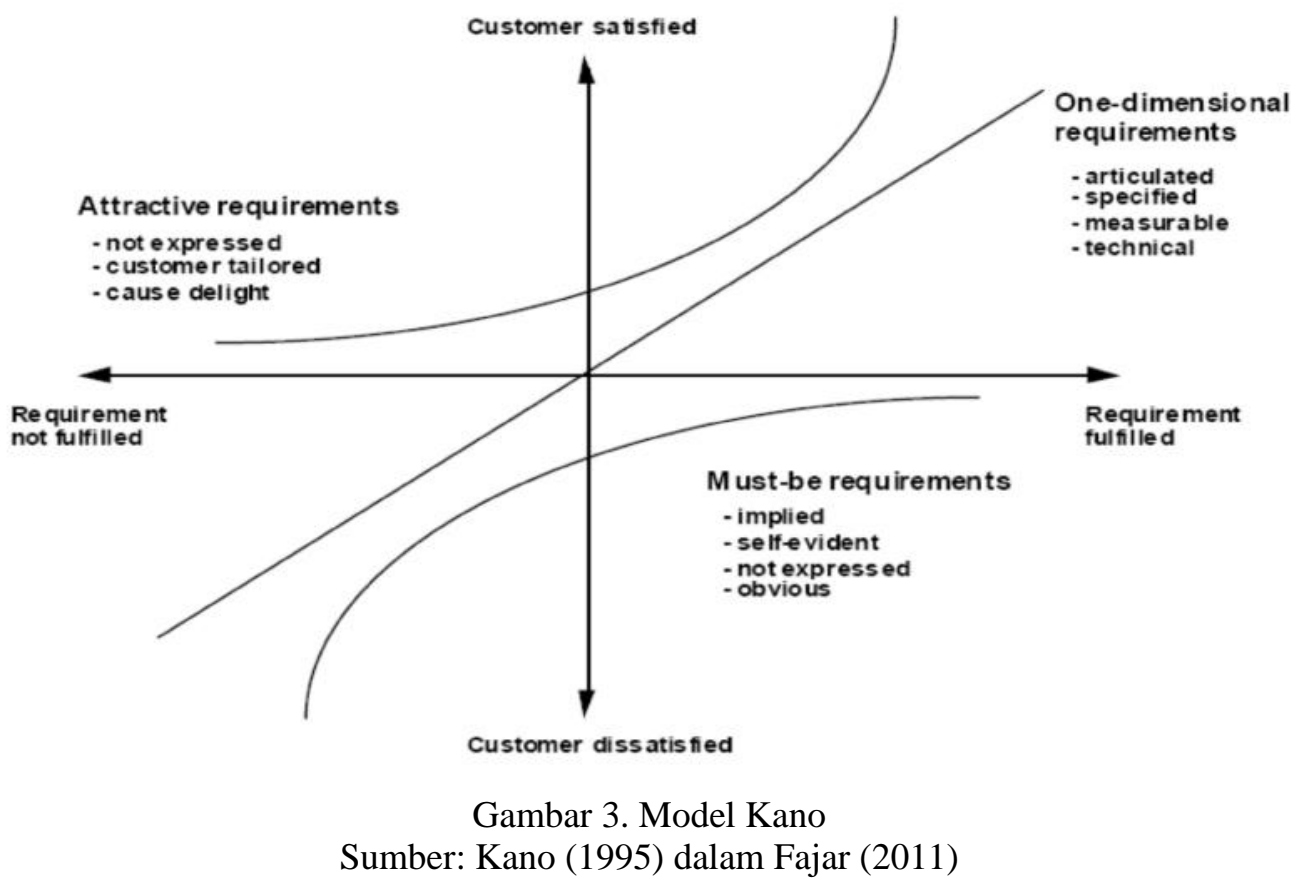

Profesor Noriaki Kano bekerjasama dengan para mahasiswanya memunculkan beberapa ide yang menjadi cikal bakalnya perkembangan Model Kano, ide-ide tersebut dapat dirangkum sebagai berikut:

1) Ide atau permintaan mengenai kualitas yang tidak dapat dilihat bisa dibuat dapat melihat. Para pelanggan biasanya memiliki ide atau permintaan dan mudah untuk dilihat.

2) Untuk beberapa permintaan pelanggan, kepuasan pelanggan adalah seberapa besar suatu produk/ jasa dapat berfungsi secara maksimal. Pada gambar 2 Model Kano diterjemahkan dengan did it very well yang diletakkan pada bagian kanan dari garis horizontal.

3) Beberapa permintaan pelanggan tidak hanya one dimensional (satu dimensi) atau performance needs (kebutuhan kinerja) atau linear tapi juga attractive atau excitement needs (butuh semangat) atau delighters atau must-be basic needs (harus menjadi kebutuhan dasar) atau thereshold.
4) Permintaan pelanggan dapat diklasifikasikan dengan menggunakan kuisioner.

Dalam model Kano yang dapat dilihat dari Gambar 3, kategori dari suatu produk dapat dibedakan menjadi:

1) Must-be atau basic needs atau thereshold: pelanggan tidak puas apabila kinerja dari atribut yang bersangkutan rendah. Tetapi kepuasan pelanggan tidak akan meningkat jauh diatas netral meskipun kinerja dari atribut tersebut tinggi.

2) One dimensional atau performance needs atau linear: tingkat kepuasan pelanggan berhubungan linier dengan kinerja atribut, sehingga kinerja atribut yang tinggi akan mengakibatkan tingginya kepuasan pelanggan pula.

3) Attractive atau exswcitement needs atau delighters: tingkat kepuasan pelanggan akan meningkat sangat tinggi dengan meningkatnya kinerja atribut. Akan tetapi penurunan kinerja atribut tidak akan menyebabkan penurunan tingkat kepuasan. 


\section{Suryalena \& Sri, Analisis Kepuasan Konsumer}

4) Reverse apabila tingkat kepuasan pelanggan berbanding terbalik dengan hasil kinerja atribut, questionable result (hasil yang dipertanyakan) apabila tingkat kepuasan pelanggan tidak dapat didefinisikan (terdapat kontradiksi pada jawaban pelanggan) atau indifferent apabila tingkat kepuasan pelanggan tidak berpengaruh dari hasil kinerja atribut.

Dengan memperhatikan Model Kano, menuntut perusahaan menciptakan produk/ jasa inovatif yang dapat menarik perhatian pelanggan diatas must-be dan one dimensional.

e. Komunitas Konsumen (Consumer

Komunitas pelanggan adalah komunitas yang tidak terikat secara geografi dan mempunyai struktur sosial yang mengatur hubungan di antara pencinta merek. Komunitas pelanggan merupakan customer centric, keberadaan dan arti dari komunitas tidak terpisahkan dari pengalaman konsumen daripada merek tersebut. Komunitas merek juga tidak terlepas dari interaksi antar anggotanya agar memperkuat soliditas komunitas pelanggan. (Mc Alexander, Schouten, dan Koeing, 2002).

Komunitas merek terdiri dari konsumen yang sangat loyal pada merek tertentu. Merek tersebut hanya memfasilitasi terjadinya interaksi antar konsumen (Yuswohady, 2008). Semakin intens interaksi antar anggota, semakin kuat basis konsumen dalam komunitas merek. Anggota komunitas ini dihubungkan dengan merek yang menghubungkannya dengan komunitas tersebut seperti Yamaha V-ixion Club merek Yamaha. Kuatnya hubungan yang kuat antar anggota dalam komunitas merek membuat anggota komunitas merek menjadi juru bicara kepada orang lain.

\section{METODE}

Penelitian ini mengambil lokasi di Kecamatan Bangkinang Kota, Kabupaten Kampar, Riau. Alasan peneliti adalah karena terdapat komunitas pengguna Yamaha Vixion Club Bangkinang sehingga sesuai dengan kebutuhan penelitian ini. Jangka waktu penelitian ini sekitar 1 (satu) tahun pada tahun 2015. Menurut Sugiyono (2010) populasi adalah wilayah generalisasi yang terdiri atas objek/subjek yang mempunyai kualitas dan karakteristik tertentu yang ditetapkan oleh peneliti untuk dipelajari dan kemudian ditarik kesimpulannya. Populasi penelitian dalam penyusunan penelitian ini adalah seluruh anggota komunitas Yamaha Vixion Club (YVC) yang aktif pada tahun 2015, yaitu berjumlah 30 orang. Teknik penentuan sampel menggunakan sensus adalah teknik penentuan sampel bila semua anggota populasi digunakan sebagai sampel (Sugiyono, 2010). Sampel ditetapkan dari anggota komunitas yang aktif. Maka seluruh populasi dijadikan sebagai responden dalam penelitian ini, yaitu sebanyak 30 konsumen.

Data yang digunakan dalam penelitian ini adalah:

1. Data Primer

Data primer merupakan sumber data yang langsung memberikan data kepada pengumpul data (Sugiyono, 2010). Data primer pada penelitian ini adalah data yang diperoleh dari questionnaire, yaitu tanggapan responden mengenai kepuasan konsumen dalam menggunakan sepeda motor Yamaha Vixion.

2. Data Sekunder

Data sekunder merupakan sumber data yang diperoleh peneliti secara tidak langsung melalui media perantara (diperoleh dan dicatat oleh pihak lain). Data sekunder pada penelitian ini adalah data pendukung berkaitan dengan penelitian. Juga data mengenai gambaran umum Kecamatan Bangkinang Kota, Kabupaten Kampar, Riau

Teknik pengumpulan data yang digunakan dalam penelitian ini adalah dengan menggunakan instrumen questionnaire, yakni pengumpulan data yang berupa daftar pertanyaan yang disampaikan kepada responden untuk dijawab secara tertulis (Riyanto, 2001). Questionnaire yang disusun mempunyai sepasang pertanyaan untuk setiap pertanyaannya. Sepasang pertanyaan tersebut adalah pertanyaan apabila atribut tersebut terpenuhi (functional questions) sedangkan pertanyaan lain merupakan kebalikannya yakni apabila atribut tersebut tidak terpenuhi (disfunctional questions).

Analisis data yang digunakan pada penelitian ini adalah analisis deskriptif dan kuantitatif. Analisis ini dilakukan untuk mendapatkan gambaran deskriptif mengenai 
responden penelitian ini, khususnya mengenai variabel penelitian yang digunakan. Analisis ini dilakukan dengan menggunakan teknik analisis model Kano untuk menganalisis tanggapan responden atas item-item pertanyaan yang diajukan.
Setelah data terkumpul, peneliti selanjutnya melakukan pengolahan data pada penelitian dengan menggunakan langkah model kano yang dapat dipahami melalui gambar 4 berikut:

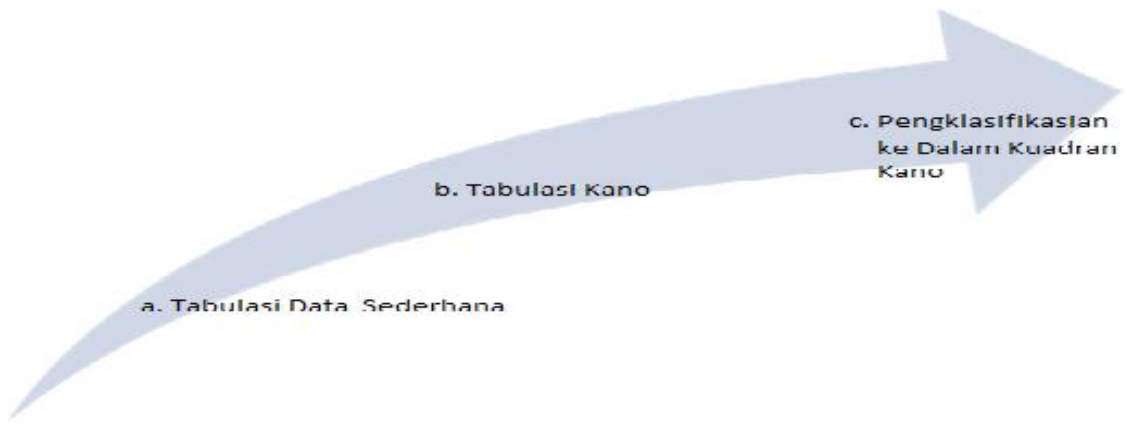

Gambar 4. Langkah Model Kano

Sumber: Data Olahan, 2015

Secara sistematis, langkah-langkah dalam pengolahan data model Kano sebagai berikut:

1. Tabulasi Data Sederhana

Langkah pertama dalam menganalisis kepuasan konsumen menggunakan model Kano adalah membuat tabel yang memuat jawabanjawaban orisinil responden dalam bentuk pengkodean huruf atau yang dikenal dengan tabulasi. Pada pengolahan data penelitian ini, format tabel tabulasi data sederhana konsisten dengan model Kano (Kano, 1995) dalam Fajar (2011) yang dapat dilihat pada tabel III.1 berikut ini.

Tabel 3. Tabulasi Data Kano

\begin{tabular}{|c|c|c|c|c|c|c|}
\hline \multirow{2}{*}{\multicolumn{2}{|c|}{$\begin{array}{c}\text { Customer } \\
\text { Requirements }\end{array}$}} & \multicolumn{5}{|c|}{ Disfuncional } \\
\hline & & Like & Must-be & Neutral & Live With & Dislike \\
\hline \multirow{5}{*}{ 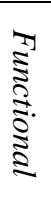 } & 1. Like & $\mathrm{Q}$ & A & $\mathrm{A}$ & $\mathrm{A}$ & $\mathrm{O}$ \\
\hline & 2. Must-be & $\mathrm{R}$ & $\mathrm{I}$ & $\mathrm{I}$ & $\mathrm{I}$ & $\mathrm{M}$ \\
\hline & 3. Neutral & $\mathrm{R}$ & I & I & I & $M$ \\
\hline & 4. Live with & $\mathrm{R}$ & $\mathrm{I}$ & $\mathrm{I}$ & $\mathrm{I}$ & $\mathrm{M}$ \\
\hline & 5. Dislike & $\mathrm{R}$ & $\mathrm{R}$ & $\mathrm{R}$ & $\mathrm{R}$ & Q \\
\hline
\end{tabular}

Sumber: Kano,1995 (dalam Fajar, 2011)

Keterangan:

$\mathrm{A}=$ Attractive $:$ menggambarkanakan adanya peningkatan konsumen jika produk tersebut berfungsi lebih baik dari biasanya, tetapi kepuasannya tidak akan menurun jika produk tidak berfungsi lebih baik dari fungsi biasanya.

$\mathrm{M}=$ Must-be : menggambarkan semakin suatu produk tidak berfungsi dengan semestinya, maka kepuasan konsumen akan semakin menurun, tetapi kepuasan 
Suryalena \& Sri, Analisis Kepuasan Konsumer

konsumen tidak akan meningkat walaupun produk tersebut berfungsi dengan baik.

$\mathrm{R}=$ Reverse : penetapan dari perusahaan terbalik dengan apa yang dirasakan oleh konsumen

$\mathrm{D}=$ One-Dimensional : menggambarkan kepuasan konsumen akan meningkat jika sebuah produk semakin berfungsi dengan baik, dan sebaliknya kepuasan konsumen akan menurun jika sebuah produk tidak berfungsi dengan semestinya.

$\mathrm{Q}=$ Questionable : jawaban dari konsumen (responden) tidak jelas atau kurang sesuai dengan pertanyaan yang ada.
$\mathrm{I}=$ Indifferent $:$ kepuasan konsumen tidak dipengaruhi oleh sifat produk yang fungsional atau tidak fungsional.

2. Tabulasi Kano

Setelah selesai melakukan tabulasi data sederhana, langkah kedua yaitu tabulasi Kano. Secara sederhana, tabulasi Kano adalah pekerjaan membuat tabel yang memuat kode huruf dan konsisten dengan model Kano (1995) dalam Fajar (2011). yang berbeda dengan tabulasi data sederhana adalah, bahwa langkah ini merupakan proses lanjutan dari tabulasi data sederhana dengan cara jawaban-jawaban orisinil dari responden dikonversikan/ diterjemahkan menjadi enam kategori jawaban Kano yang baru. Adapun enam kategori jawaban Kano seperti pada tabel 4 berikut.

Tabel 4. Enam Kategori Kano

\begin{tabular}{|c|l|c|l|}
\hline $\mathrm{A}$ & Attractive & $\mathrm{R}$ & Reverse \\
\hline $\mathrm{M}$ & Must be & $\mathrm{I}$ & Indifferent \\
\hline $\mathrm{O}$ & One dimensionl & $\mathrm{Q}$ & Questionable \\
\hline
\end{tabular}

Sumber: Kano,1995 (dalam Fajar, 2011)

Ditegaskan kembali, bahwa penggolongan jawaban-jawaban konsumen ke dalam enam kategori Kano diatas, merupakan hasil dari penerjemahan dan pengkombinasian jawaban orisinil responden. Tabel 5 berikut menjelaskan secara rinci teknis penerjemahan jawaban orisinil responden menjadi enam kategori Kano.

Tabel 5. Tabel Tabulasi Kano

\begin{tabular}{|c|c|c|c|c|c|}
\hline No. & FA & DFA & \multicolumn{2}{|c|}{ Combination of FA and DFA } & $\mathrm{KE}$ \\
\hline 1 & Like & Like & Like & Like & Questionable (Q) \\
\hline 2 & Like & Must be & Like & Must be & Attractive (A) \\
\hline 3 & Like & Neutral & Like & Neutral & Attractive (A) \\
\hline 4 & Like & Live-with & Like & Live-with & Attractive (A) \\
\hline 5 & Like & Dislike & Like & Dislike & One dimensional $(\mathrm{O})$ \\
\hline 6 & Must be & Like & Must be & Like & Reverse (R) \\
\hline 7 & Must be & Must be & Must be & Must be & Indifferent $(\mathrm{I})$ \\
\hline 8 & Must be & Neutral & Must be & Neutral & Indifferent $(\mathrm{I})$ \\
\hline 9 & Must be & Live-with & Must be & Live-with & Indifferent $(\mathrm{I})$ \\
\hline 10 & Must be & Dislike & Must be & Dislike & Must be (M) \\
\hline 11 & Neutral & Like & Neutral & Like & Reverse (R) \\
\hline 12 & Neutral & Must be & Neutral & Must be & Indifferent (I) \\
\hline 13 & Neutral & Neutral & Neutral & Neutral & Indifferent (I) \\
\hline 14 & Neutral & Live-with & Neutral & Live-with & Indifferent (I) \\
\hline 15 & Neutral & Dislike & Neutral & Dislike & Must be (M) \\
\hline 16 & Live-with & Like & Live-with & Like & Reverse (R) \\
\hline 17 & Live-with & Must be & Live-with & Must be & Indifferent $(\mathrm{I})$ \\
\hline
\end{tabular}


Journal of Applied Business Administration Vol 1, No 1, Maret 2017, hlm. 122-138

\begin{tabular}{|l|l|l|l|l|l|}
\hline 18 & Live-with & Neutral & Live-wisth & Neutral & Indifferent $(\mathrm{I})$ \\
\hline 19 & Live-with & Live-with & Live-with & Live-with & Indifferent $(\mathrm{I})$ \\
\hline 20 & Live-with & Dislike & Live-with & Dislike & Must be $(\mathrm{M})$ \\
\hline 21 & Dislike & Like & Dislike & Like & Reverse $(\mathrm{R})$ \\
\hline 22 & Dislike & Must be & Dislike & Must be & Reverse $(\mathrm{R})$ \\
\hline 23 & Dislike & Neutral & Dislike & Neutral & Reverse (R) \\
\hline 24 & Dislike & Live-with & Dislike & Live-with & Reverse (R) \\
\hline 25 & Dislike & Dislike & Dislike & Dislike & Questionable (Q) \\
\hline
\end{tabular}

Sumber: Kano, 1995 (dalam Fajar, 2011)

Keterangan:

$\begin{array}{ll}\text { FA } & \text { : Functional Answer } \\ \text { DA } & : \text { Dysfunctional Answer } \\ \text { KE } & : \text { Kano Evaluation }\end{array}$

3. Pengklasifikasian kedalam Kuadran Kano

Berdasarkan tabel 5 bahwa jawabanjawaban orisinil responden atas setiap pasangan pertanyaan (functional dan disfunctional) pada kuesioner yang dimuat dalam tabulasi data sederhana, diterjemahkan dan dikombinasikan sehingga menghasilkan jawaban baru yaitu salah satu dari enam kategori Kano. Misalnya, apabila pertanyaan functional dijawab like dan pertanyaan disfunctional dijawab must be maka kombinasi dari keduanya (like - must be) masuk ke dalam kategori attractive (A), atau apabila pertanyaan functional dijawab like dan disfunctional dijawab dislike maka kombinasi dari keduanya (like - dislike) masuk dalam kategori one dimensional $(\mathrm{O})$.

Menetapkan Kuadran atribut adalah langkah terakhir dalam model Kano. Langkah ini memetakan tiap atribut pertanyaan kedalam kuadran Kano berdasarkan perhitungan koefisien kepuasan konsumen yang dikemukakan oleh Kano (1995) dalam Fajar (2011):

Koefisien kepuasan:

$$
\frac{\mathrm{A}+\mathrm{O}}{\mathrm{A}+\mathrm{O}+\mathrm{M}+\mathrm{I}}
$$

Koefisien ketidakpuasan:

$$
\mathrm{O}+\mathrm{M}
$$

$$
(\mathrm{A}+\mathrm{O}+\mathrm{M}+\mathrm{I}) \times(-1)
$$

Terlihat bahwa untuk kategori $\mathrm{R}$ (reverse) dan $\mathrm{Q}$ (questionable) tidak diikutsertakan dalam perhitungan. Hal ini dikarenakan kategori $\mathrm{R}$ mengindikasikan bahwa pemikiran responden tentang pertanyaan kuesioner bertentangan dengan keinginan peneliti. Adapun kategori Q dapat dihilangkan dari analisis sampai kebingungan yang dialami responden dapat diselesaikan.

Setelah didapatkan nilai kedua koefisien untuk tiap atributnya, langkah selanjutnya adalah memetakan tiap atribut ke dalam kuadran Kano dengan ketentuan sebagai berikut:

1) Kategori mustbe mempunyai nilai koefisien ketidakpuasan tinggi dan nilai koefieien kepuasan rendah.

2) Kategori one dimensional mempunyai nilai yang tinggi pada koefisien kepuasan dan ketidakpuasan.

3) Kategori attractive mempunyai nilai koefisien kepuasan yang tinggi dan nilai koefisien ketidakpuasan yang rendah.

4) Kategori indifferent mempunyai nilai yang rendah pada koefisien kepuasan dan ketidakpuasannya.

Untuk membagi kuadran Kano ke dalam empat bagian sesuai dengan keempat kategori tersebut, dilakukan dengan cara menarik dua garis yang saling tegak lurus dimana kedua garis tersebut berasal dari nilai rata-rata koefisien kepuasan dan ketidakpuasan yang dihitung dengan rumus sebagai berikut: 
Suryalena \& Sri, Analisis Kepuasan Konsumer

$$
\begin{aligned}
& X=\frac{\sum \mathrm{Xi}}{\mathrm{n}} \\
& Y=\frac{\sum \mathrm{Yi}}{\mathrm{n}}
\end{aligned}
$$

Dimana:

$\mathrm{X}=$ skor rata - rata nilai koefisien kepuasan

$\mathrm{Y}=$ skor rata - rata nilai koefisien ketidakpuasan

$\mathrm{n}=$ jumlah atribut

HASIL DAN PEMBAHASAN

A. Deskripsi Karakteristik Responden

\begin{tabular}{|c|c|c|c|}
\hline No. & Karakteristik & Frekuensi & $\begin{array}{c}\text { Persentase } \\
(\%)\end{array}$ \\
\hline 1. & $\begin{array}{l}\text { Jenis kelamin } \\
\text { Laki-laki } \\
\text { Perempuan }\end{array}$ & $\begin{array}{c}30 \\
0\end{array}$ & $\begin{array}{c}100,00 \\
0\end{array}$ \\
\hline 2. & $\begin{array}{l}\text { Kelompok } \\
\text { usia } \\
<20 \text { tahun } \\
20-29 \text { tahun } \\
30-39 \text { tahun } \\
40-49 \text { tahun } \\
50 \text { tahun dan } \\
\text { keatas }\end{array}$ & $\begin{array}{c}9 \\
11 \\
5 \\
4 \\
1\end{array}$ & $\begin{array}{c}30,00 \\
36,67 \\
16,67 \\
13,33 \\
3,33\end{array}$ \\
\hline 3. & $\begin{array}{l}\text { Jenis } \\
\text { pekerjaan } \\
\text { PNS } \\
\text { Wiraswasta } \\
\text { Pegawai } \\
\text { swasta } \\
\text { Pelajar/ } \\
\text { mahasiswa }\end{array}$ & $\begin{array}{c}3 \\
8 \\
4 \\
15\end{array}$ & $\begin{array}{l}10,00 \\
26,67 \\
13,33 \\
50,00\end{array}$ \\
\hline 4. & $\begin{array}{l}\text { Rerata } \\
\text { kelompok } \\
\text { pendapatan } \\
\text { per bulan } \\
< \\
\text { Rp.2.000.000,- } \\
\text { Rp.2.000.000,- } \\
\text { sd. } \\
\text { Rp.2.999.000,- } \\
\text { Rp.3.000.000,- } \\
\text { sd. } \\
\text { Rp.3.999.000,- } \\
\text { Rp.4.000.000,- } \\
\text { sd. } \\
\text { Rp.4.999.000,- }\end{array}$ & $\begin{array}{l}16 \\
5 \\
6 \\
2 \\
1\end{array}$ & $\begin{array}{c}53,33 \\
16,67 \\
20,00 \\
6,67 \\
3,33\end{array}$ \\
\hline
\end{tabular}

Tabel 6. Karakteristik Responden Penelitian

\begin{tabular}{|c|l|l|}
\hline & $>5.000 .000$ & \\
\hline Sumber: Data olahan, 2016 & \\
\hline
\end{tabular}

Berdasarkan data pada tabel 6 , diketahui bahwa keseluruhan responden dalam penelitian ini berjenis kelamin laki - laki yaitu sebanyak 30 orang. Mayoritas berada pada kelompok usia muda, yakni antara 20 sd. 29 tahun, diikuti kelompok usia kurang dari 20 tahun, selanjutnya pada kelompok usia antara 30 hingga 39 tahun.

Sedangkan jika dilihat dari jenis pekerjaan responden, ternyata responden didominasi oleh pelajar/ mahasiswa yaitu sebanyak $50 \%$. Sehingga jika responden disegmen berdasarkan rerata pendapatan per bulan, lebih separuh atau $53,33 \%$ berada pada kelompok rerata pendapatan per bulan < Rp.2.000.000,-. Diikuti kelompok pendapatan Rp.3.000.000,- sd. Rp. 3.999.000,sebesar 20\% dan Rp.2.000.000,- sd. Rp.2.999.000,- sebanyak 5 responden (16,67\%).

\section{B. Analisis Kepuasan Konsumen Menggunakan Sepeda Motor Yamaha Vixion dengan Pendekatan Kano \\ 1. Tanggapan (Orisinil) Responden mengenai Kepuasan Konsumen}

Data mentah yang didapat dari 30 responden untuk masing-masing item pertanyaan terdiri dari 2 bagian, yaitu:

a. Kepuasan konsumen terhadap adanya indicator (Functional Answer/ FA)

b. Kepuasan konsumen terhadap tidaka danya indicator (Disfunctional Answer) $D F A$ )

Keseluruhan jawaban 30 responden mengenai kepuasan konsumen yang terdiri dari 5 dimensi, yaitu kualitas produk, harga, kualitas jasa, emosional dan biaya atau kemudahan untuk mendapatkan produk/ jasa seperti dirincikan pada tabel V.2 yaitu tabulasi data sederhana. Alternatif jawaban yang disediakan pada questionnaire konsisten dengan model Kano, yaitu
a. Tidak suka (dislike)
b. Bisa diterima (live with)
c. Netral (neutral)
d. Sudah seharusnya ada (must be)
e. Suka (like)

Tabel 7. Tabulasi Data Sederhana

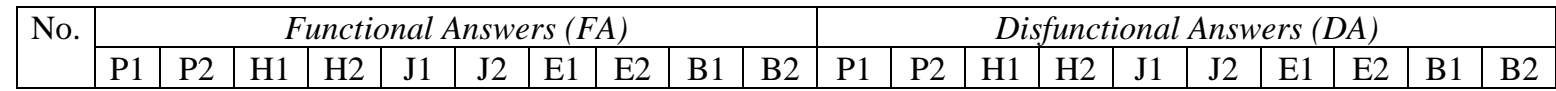


Journal of Applied Business Administration Vol 1, No 1, Maret 2017, hlm. 122-138

\begin{tabular}{|c|c|c|c|c|c|c|c|c|c|c|c|c|c|c|c|c|c|c|c|c|}
\hline 1 & $\mathrm{~L}$ & $\mathrm{~L}$ & M & W & L & L & $\mathrm{L}$ & $\mathrm{L}$ & M & $\mathrm{Lw}$ & $\mathrm{Lw}$ & $\mathrm{M}$ & D & $\mathrm{D}$ & D & M & M & $\mathrm{M}$ & $\mathrm{Lw}$ & LV \\
\hline 2 & $\mathrm{~L}$ & $\mathrm{~L}$ & $\mathrm{Lw}$ & $\mathrm{L}$ & $I$ & $\mathrm{~L}$ & & 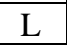 & $M$ & $\mathrm{M}$ & 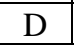 & $\mathrm{Lw}$ & $\mathrm{I}$ & $\Gamma$ & $\mathrm{D}$ & $\mathrm{N}$ & $\mathrm{N}$ & $\mathrm{N}$ & $\mathrm{w}$ & $\mathrm{w}$ \\
\hline 3 & $M$ & $\mathrm{~L}$ & $\mathrm{~N}$ & Lw & $\mathrm{L}$ & $\mathrm{I}$ & & $\mathrm{I}$ & Lw & M & $\mathrm{L}$ & $\mathrm{D}$ & $\mathrm{D}$ & $\mathrm{D}$ & M & $\mathrm{D}$ & LW & $\mathrm{LW}$ & $\mathrm{M}$ & $\mathrm{LW}$ \\
\hline 4 & $\mathrm{~L}$ & L & $\mathrm{N}$ & $\mathrm{Lw}$ & $\mathrm{L}$ & $I_{1}$ & & $\mathrm{~L}$ & $\mathrm{Lw}$ & $\mathrm{M}$ & $\mathrm{D}$ & $\mathrm{Lw}$ & $\mathrm{D}$ & $\mathrm{D}$ & $\mathrm{N}$ & $\mathrm{D}$ & $\mathrm{M}$ & $\mathrm{M}$ & $\bar{M}$ & $\mathrm{~W}$ \\
\hline 5 & 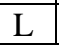 & $T$ & $M$ & $\mathrm{Lw}$ & $\mathrm{L}$ & $\mathrm{I}$ & & $\mathrm{L}$ & $\mathrm{Lw}$ & $\mathrm{M}$ & $\mathrm{N}$ & 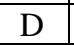 & D & D & $\mathrm{Lw}$ & $M$ & $N$ & $\mathrm{~N}$ & $\mathrm{M}$ & $\mathrm{WW}$ \\
\hline$\overline{6}$ & $\bar{L}$ & $\mathrm{~L}$ & $\mathrm{M}$ & $\mathrm{Lw}$ & $\bar{L}$ & & & & 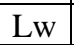 & $\bar{M}$ & $\mathrm{D}$ & D & 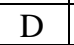 & $\mathrm{D}$ & $\begin{array}{ll}\mathrm{w} \\
\end{array}$ & $\mathrm{N}$ & $\mathrm{Lw}$ & $\mathrm{Lw}$ & $\bar{M}$ & $\mathrm{w}$ \\
\hline 7 & L & $\mathrm{I}$ & $\mathrm{L}$ & $\mathrm{Lw}$ & L & & & & $\mathrm{w}$ & $M$ & $M$ & $\mathrm{Lw}$ & $\mathrm{Lw}$ & $\mathrm{D}$ & $\mathrm{w}$ & Lw & $M$ & $M$ & $M$ & $\mathrm{~V}$ \\
\hline 0 & L & L & $\mathrm{L}$ & -1 & $\mathrm{M}$ & L & I & L & $M$ & $\mathrm{M}$ & $\mathrm{D}$ & $\mathrm{D}$ & $\mathrm{Lw}$ & $\mathrm{Lw}$ & $\mathrm{Lw}$ & $M$ & $\mathrm{~N}$ & $\mathrm{~N}$ & $\mathrm{Lw}$ & $\mathrm{w}$ \\
\hline S & 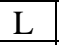 & $\mathrm{L}$ & $\mathrm{L}$ & $\mathrm{M}$ & $\mathrm{M}$ & 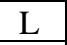 & 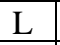 & 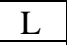 & Lw & $\mathrm{M}$ & $\mathrm{N}$ & D & Lw & $\mathrm{D}$ & $\mathrm{D}$ & $\mathrm{N}$ & $\mathrm{Lw}$ & Lw & $\mathrm{M}$ & $\mathrm{Lw}$ \\
\hline 10 & L & 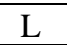 & $\mathrm{L}$ & $\mathrm{M}$ & $\mathrm{N}$ & L & I & L & Lw & M & D & & $\mathrm{Lw}$ & D & D & Lw & $\mathrm{M}$ & $\mathrm{M}$ & M & Lw \\
\hline 11 & $\mathrm{~L}$ & $\mathrm{~L}$ & $\mathrm{M}$ & $M$ & $\mathrm{Lw}$ & L & L & $\mathrm{M}$ & $\mathrm{Lw}$ & M & $N$ & J & $\mathrm{D}$ & $\mathrm{D}$ & D & $\mathrm{M}$ & $\mathrm{D}$ & $\mathrm{D}$ & $\mathrm{M}$ & $\mathrm{Lw}$ \\
\hline 12 & L & $\mathrm{L}$ & L & $\mathrm{L}$ & $\mathrm{L}$ & L & & $\mathrm{N}$ & M & $\mathrm{M}$ & $\mathrm{D}$ & Lw & D & 101 & $\mathrm{M}$ & $\mathrm{D}$ & ) & ) & Lw & $\mathrm{LW}$ \\
\hline 13 & 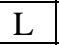 & $\mathrm{L}$ & $\mathrm{L}$ & $\bar{N}$ & 1 & $\mathrm{~L}$ & & $\mathrm{~L}$ & $\mathrm{Lw}$ & $\mathrm{M}$ & $\mathrm{Lw}$ & $\mathrm{Lw}$ & $\mathrm{D}$ & $\mathrm{Lw}$ & $\mathrm{N}$ & L & $\bar{D}$ & $\mathrm{D}$ & $\mathrm{M}$ & $\mathrm{Lw}$ \\
\hline 14 & L & $\mathrm{L}$ & $\mathrm{Lw}$ & 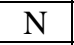 & & & & $\mathrm{L}$ & $\mathrm{M}$ & $\mathrm{M}$ & 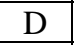 & $\mathrm{D}$ & $\mathrm{D}$ & Lw & Lw & $\mathrm{Lw}$ & D & $\mathrm{D}$ & & $\mathrm{Lw}$ \\
\hline 15 & $\mathrm{~L}$ & 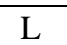 & $\mathrm{M}$ & $\bar{M}$ & I & $\mathrm{L}$ & $\mathrm{M}$ & $\mathrm{w}$ & $\mathrm{w}$ & $M$ & $\mathrm{~N}$ & D & D & $\mathrm{D}$ & $\mathrm{Lw}$ & $\mathrm{LW}$ & $\mathrm{D}$ & $\mathrm{D}$ & $\mathrm{M}$ & $\overline{\mathrm{LW}}$ \\
\hline 16 & L & $\mathrm{M}$ & $\mathrm{M}$ & $\mathrm{M}$ & L & L & $\mathrm{N}$ & Lw & $\mathrm{Lw}$ & M & D & L & D) & D & Lw & $\mathrm{L}$ & $\mathrm{D}$ & $\mathrm{D}$ & $\mathrm{M}$ & Lw \\
\hline 17 & I & $\mathrm{L}$ & $\mathrm{L}$ & $\mathrm{Lw}$ & $\mathrm{L}$ & $\mathrm{L}$ & $\mathrm{M}$ & $\mathrm{I}$ & $\mathrm{M}$ & $\mathrm{M}$ & $\mathrm{Lw}$ & $\mathrm{D}$ & & $\mathrm{D}$ & M & $\mathrm{L}$ & & 5 & $\mathrm{w}$ & $\mathrm{Lw}$ \\
\hline 18 & $\mathrm{I}$ & Lw & $\mathrm{L}$ & 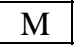 & 1 & $\mathrm{Lw}$ & 1 & & $\mathrm{M}$ & $\mathrm{M}$ & $\mathrm{D}$ & $\mathrm{Lw}$ & D & D & $\mathrm{N}$ & $M$ & D & $\mathrm{D}$ & $\mathrm{Lw}$ & $\mathrm{Lw}$ \\
\hline 19 & 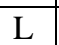 & . & 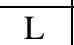 & $\mathrm{M}$ & $\mathrm{M}$ & $\mathrm{L}$ & $M$ & Lw & $\mathrm{Lw}$ & $\mathrm{L}$ & $\mathrm{Lw}$ & $\mathrm{D}$ & $\mathrm{D}$ & $D_{1}$ & $\mathrm{~N}$ & $\mathrm{M}$ & LW & $\mathrm{Lw}$ & $\mathrm{M}$ & M \\
\hline 20 & $\mathrm{~L}$ & IV & $\mathrm{L}$ & $\mathrm{M}$ & 10 & L & $\mathrm{L}$ & 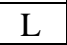 & $\mathrm{Lw}$ & $\mathrm{L}$ & $\mathrm{D}$ & $\mathrm{Lw}$ & $\mathrm{D}$ & $\mathrm{D}$ & $\mathrm{N}$ & $\mathrm{N}$ & $\mathrm{M}$ & $\mathrm{M}$ & $\mathrm{M}$ & $\mathrm{D}$ \\
\hline 21 & $\mathrm{~L}$ & $\mathrm{~L}$ & $\mathrm{~L}$ & $\mathrm{M}$ & $\mathrm{L}$ & L & $\mathrm{L}$ & L & Lw & $\mathrm{M}$ & $\mathrm{Lw}$ & D & $D$ & D & $M$ & $\mathrm{Lw}$ & $\mathrm{N}$ & $\mathrm{N}$ & $M$ & D \\
\hline 22 & $\mathrm{~L}$ & $\mathrm{~N}$ & $\mathrm{Lw}$ & $\mathrm{M}$ & 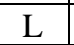 & $\mathrm{M}$ & $T_{1}$ & $\pi$ & $\mathrm{M}$ & $\mathrm{L}$ & $\mathrm{D}$ & $\mathrm{N}$ & $D$ & $\mathrm{D}$ & $\mathrm{N}$ & $\mathrm{D}$ & $\mathrm{Lw}$ & $\mathrm{Lw}$ & $\mathrm{Lw}$ & $\mathrm{D}$ \\
\hline 23 & $I$ & $\mathrm{M}$ & $\mathrm{M}$ & $\mathrm{M}$ & -1 & $\mathrm{~N}$ & - & & $\mathrm{Lv}$ & $\mathrm{L}$ & & 4 & $\mathrm{Lw}$ & D & 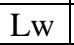 & & 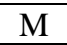 & $\pi$ & $\mathrm{M}$ & D \\
\hline 24 & $\mathrm{~L}$ & $\mathrm{~L}$ & $\mathrm{Lw}$ & $\mathrm{M}$ & $\bar{L}$ & v & $\mathrm{L}$ & $\overline{\mathrm{L}}$ & $\bar{M}$ & $\mathrm{~L}$ & D & $\mathrm{D}$ & $D$ & $\mathrm{D}$ & $\mathrm{Lw}$ & $\mathrm{D}$ & $\mathrm{N}$ & $\mathrm{N}$ & $\mathrm{Lw}$ & $\bar{D}$ \\
\hline 25 & $L$ & $\mathbf{N}$ & $\mathrm{Lv}$ & $N_{v}$ & $L$ & $\mathrm{~N}$ & L & I & $\mathrm{Lv}$ & $\mathrm{L}$ & & $\mathrm{N}$ & $w$ & $\mathrm{Lw}$ & $\mathrm{Lw}$ & $\mathrm{D}$ & $\mathrm{w}$ & $\mathrm{Lw}$ & $\mathrm{M}$ & D \\
\hline 26 & $\mathrm{~L}$ & $\mathrm{~L}$ & $\mathrm{~N}$ & $\mathrm{~N}$ & $\mathrm{~L}$ & $\mathrm{Lw}$ & $\mathrm{L}$ & $\mathrm{L}$ & Lw & $\mathrm{L}$ & $\mathrm{D}$ & $\mathrm{D}$ & $\mathrm{Lw}$ & Lw & $\mathrm{M}$ & $\mathrm{D}$ & $\mathrm{M}$ & $\mathrm{M}$ & $\mathrm{M}$ & $\mathrm{D}$ \\
\hline 27 & 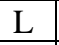 & Lw & $\mathrm{M}$ & $\mathrm{M}$ & $\mathrm{L}$ & $\mathrm{Lu}$ & $\mathrm{L}$ & $\mathrm{L}$ & $\mathrm{Lw}$ & $\mathrm{L}$ & $\mathrm{D}$ & $\mathrm{M}$ & $\mathrm{D}$ & $\mathrm{M}$ & iv & D & Iv & IV & $\mathrm{M}$ & D \\
\hline 28 & L & $\mathrm{I}_{\mathrm{s}}$ & $\mathrm{M}$ & $\mathrm{M}$ & L & $\mathrm{M}$ & L & 1 & $\mathrm{Lw}$ & $\mathrm{N}$ & $D$ & $\mathrm{Lw}$ & $\mathrm{D}$ & M & $\mathrm{Lw}$ & $\mathrm{D}$ & Lw & $\mathrm{Lw}$ & $\mathrm{M}$ & $\mathrm{D}$ \\
\hline 25 & I & L & $\mathrm{N}$ & D & L & $\mathrm{M}$ & I & I & $\mathrm{L}$ & $\mathrm{D}$ & 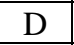 & $\mathrm{D}$ & $\mathrm{Lw}$ & $\mathrm{N}$ & Lw & D & $\mathrm{M}$ & $\mathrm{M}$ & M & L \\
\hline 30 & L & L & $\mathrm{WW}$ & $\mathrm{W}$ & $\mathrm{W}$ & $\mathrm{L}$ & L & $\mathrm{L}$ & $\mathrm{L}$ & $\mathrm{N}$ & D & $\bar{D}$ & $\mathrm{D}$ & $\mathrm{Lw}$ & $\mathrm{N}$ & $\mathrm{Lw}$ & $\mathrm{N}$ & $\mathrm{N}$ & $\mathrm{M}$ & \\
\hline
\end{tabular}

Sumber: Data Olahan, 2016

\section{Keterangan:}

P: dimensi kualitas produk

E: dimensi emosional

Lw: Live with (bisa diterima)

L: Like (suka)

Tabel 7 tersebut telah menjelaskan secara rinci tanggapan responden pada questionnaire kepuasan konsumen dalam menggunakan sepeda motor Yamaha Vixion di Kecamatan Bangkinang Kota, Kabupaten Kampar, Riau.

\section{Konversi Tanggapan Orisinil Responden menjadi Enam Kategori Kano}

Penelitian ini adalah analisis kepuasan konsumen menggunakan model Kano (1995) dalam Fajar (2001), dimana penganalisisan tidak
$\mathrm{J}$ : dimensi kualitas jasa

D: Dislike (tidaksuka)

M: Must be (sudah seharusny aada)

langsungdari sumber data tanggapan orisinil responden pada questionnaire yang telah diisi, melainkan penerjemahan (pengkonversian) dari data jawaban responden tersebut.

Secara lebih rinci, tanggapan dari 30 responden mengenai kepuasan konsumen terhadap adanya indikator (FA) dan tidak adanya indikator (DFA) dikombinasikan, kemudian peneliti mengkonversi (menerjemahkan) tanggapan responden tersebut kedalam tabele valuasi Kano, sehingga menghasilkan enam 


\section{Suryalena \& Sri, Analisis Kepuasan Konsumer}

kategori tanggapan responden yang baru, yang disebut enam kategori Kano, yaitu:

a. Attractive (A), yaitu atribut kejutan dan senang, atribut ini memberikank epuasan ketika tercapais epenuhnya, tetapi tidak menyebabkan ketidakpuasan bila tidak terpenuhi.

b. Must be (M), konsumen menjadi tidak puas ketika pelaksana anatribut rendah, namun kepuasan konsumen tidak akan meningkat di atas normal, walaupun pelaksana anatribut tinggi.

c. One Dimensional $(\mathrm{O})$, kepuasan konsumen merupakan fungsi linear dari atribut kepuasan konsumen. Pelaksanaan atribut yang tinggi mengarah kepada kepuasan konsumen yang tinggi.

d. Reverse $(R)$, konsumen menjadi tidak puas, ketika pelaksanaan atribu ttinggi. Hal ini mengacu pada rendahnya pelaksanaannya mengakibatkan kepuasan

e. Indifferent (I), mengacu pada hal yang tidak baik/ buruk. Pelaksanaan atribut tidak menghasilkan kepuasan dan ketidakpuasan konsumen.

f. Questionable (Q), dapat dipertanyakan atau menggambarkan kondisi kebingungan dari responden.

Berdasarkan tabel diatas yaitu tabulasi data sederhana, dan mengacu pada enam kategori Kano, sehingga menghasilkan tabel berikut.

Tabel 8. Tabulasi Kano (Konversi Tanggapan Orisinil Responden ke Enam Kategori Kano)

\begin{tabular}{|c|c|c|c|c|c|c|c|c|c|c|}
\hline \multirow{2}{*}{$\begin{array}{c}\text { No. } \\
\text { Resp. }\end{array}$} & \multicolumn{10}{|c|}{ Indikator Penelitian } \\
\hline & P1 & $\mathbf{P 2}$ & H1 & H2 & J1 & $\mathbf{J} 2$ & E1 & E2 & B1 & B2 \\
\hline 1 & A & $\mathrm{O}$ & $\mathrm{M}$ & $\mathrm{M}$ & $\mathrm{O}$ & A & A & A & I & I \\
\hline 2 & $\mathrm{O}$ & A & $\mathrm{M}$ & $\mathrm{O}$ & $\mathrm{O}$ & A & $\mathrm{A}$ & $\mathrm{A}$ & $\mathrm{I}$ & I \\
\hline 3 & $\mathrm{M}$ & $\mathrm{O}$ & $\mathrm{M}$ & $\mathrm{M}$ & A & $\mathrm{O}$ & $\mathrm{A}$ & A & I & I \\
\hline 4 & $\mathrm{O}$ & $\mathrm{A}$ & $\mathrm{M}$ & $\mathrm{M}$ & A & $\mathrm{O}$ & $\mathrm{A}$ & A & I & I \\
\hline 5 & $\mathrm{~A}$ & $\mathrm{O}$ & $\mathrm{M}$ & $\mathrm{M}$ & $\mathrm{A}$ & A & $\mathrm{A}$ & $\mathrm{A}$ & $\mathrm{I}$ & I \\
\hline 6 & $\mathrm{O}$ & $\mathrm{O}$ & $\mathrm{M}$ & $\mathrm{M}$ & $\mathrm{A}$ & A & $\mathrm{A}$ & A & $\mathrm{I}$ & $\mathrm{I}$ \\
\hline 7 & $\mathrm{~A}$ & $\mathrm{~A}$ & $\mathrm{~A}$ & $\mathrm{M}$ & $\mathrm{A}$ & $\mathrm{A}$ & $\mathrm{A}$ & $\mathrm{A}$ & $\mathrm{I}$ & I \\
\hline 8 & $\mathrm{O}$ & $\mathrm{O}$ & A & A & I & A & A & A & I & I \\
\hline 9 & A & $\mathrm{O}$ & A & $\mathrm{M}$ & $\mathrm{M}$ & A & A & A & $\mathrm{I}$ & I \\
\hline 10 & $\mathrm{O}$ & $\mathrm{O}$ & A & $\mathrm{M}$ & $\mathrm{M}$ & A & A & A & $\mathrm{I}$ & I \\
\hline 11 & A & $\mathrm{O}$ & $\mathrm{M}$ & $\mathrm{M}$ & $\mathrm{M}$ & A & $\mathrm{O}$ & $\mathrm{M}$ & I & I \\
\hline 12 & $\mathrm{O}$ & A & $\mathrm{O}$ & $\mathrm{O}$ & A & $\mathrm{O}$ & $\mathrm{O}$ & $\mathrm{M}$ & I & I \\
\hline 13 & A & A & $\mathrm{O}$ & I & A & $\mathrm{O}$ & $\mathrm{M}$ & $\mathrm{O}$ & I & I \\
\hline 14 & $\mathrm{O}$ & $\mathrm{O}$ & $\mathrm{M}$ & I & A & $\mathrm{O}$ & $\mathrm{M}$ & $\mathrm{O}$ & I & I \\
\hline 15 & A & $\mathrm{O}$ & $\mathrm{M}$ & $\mathrm{M}$ & A & $\mathrm{O}$ & $\mathrm{M}$ & M & I & I \\
\hline 16 & $\mathrm{O}$ & $\mathrm{M}$ & $\mathrm{M}$ & $\mathrm{M}$ & $\mathrm{A}$ & $\mathrm{O}$ & $\mathrm{M}$ & $\mathrm{M}$ & I & I \\
\hline 17 & A & $\mathrm{O}$ & $\mathrm{O}$ & $\mathrm{M}$ & A & $\mathrm{O}$ & $\mathrm{M}$ & $\mathrm{M}$ & I & I \\
\hline 18 & $\mathrm{O}$ & I & $\mathrm{O}$ & $\mathrm{M}$ & A & $\mathrm{M}$ & M & $\mathrm{M}$ & I & I \\
\hline 19 & A & $\mathrm{O}$ & $\mathrm{O}$ & $\mathrm{M}$ & I & A & I & I & I & A \\
\hline 20 & $\mathrm{O}$ & I & $\mathrm{O}$ & $\mathrm{M}$ & I & A & A & A & I & $\mathrm{O}$ \\
\hline 21 & A & $\mathrm{O}$ & $\mathrm{O}$ & $\mathrm{M}$ & A & A & $\mathrm{A}$ & A & I & $M$ \\
\hline 22 & $\mathrm{O}$ & $\mathrm{I}$ & $\mathrm{M}$ & $\mathrm{M}$ & A & M & $\mathrm{A}$ & A & I & $\mathrm{O}$ \\
\hline 23 & $\mathrm{O}$ & $\mathrm{I}$ & I & $\mathrm{M}$ & $\mathrm{A}$ & $\mathrm{M}$ & $\mathrm{A}$ & $\mathrm{A}$ & I & $\mathrm{O}$ \\
\hline 24 & $\mathrm{O}$ & $\mathrm{O}$ & $\mathrm{M}$ & $\mathrm{M}$ & A & $\mathrm{M}$ & $\mathrm{A}$ & A & I & $\mathrm{O}$ \\
\hline 25 & $\mathrm{O}$ & I & I & I & $\mathrm{A}$ & $M$ & $\mathrm{~A}$ & A & I & $\mathrm{O}$ \\
\hline 26 & $\mathrm{O}$ & $\mathrm{O}$ & I & I & A & M & A & A & I & $\mathrm{O}$ \\
\hline 27 & $\mathrm{O}$ & I & $\mathrm{M}$ & I & A & M & A & A & I & $\mathrm{O}$ \\
\hline 28 & $\mathrm{O}$ & A & $\mathrm{M}$ & I & A & M & A & A & I & $\mathrm{O}$ \\
\hline 29 & $\mathrm{O}$ & $\mathrm{O}$ & I & I & A & M & A & A & I & M \\
\hline 30 & $\mathrm{O}$ & $\mathrm{O}$ & $\mathrm{M}$ & I & I & A & A & A & A & I \\
\hline $\mathrm{Jml}(\mathrm{A})$ & 10 & 6 & 4 & 2 & 21 & 13 & 21 & 21 & 1 & I \\
\hline $\operatorname{Jml}(\mathrm{M})$ & 1 & 1 & 15 & 19 & 3 & 9 & 6 & 6 & 0 & 2 \\
\hline $\mathrm{Jml}(\mathrm{O})$ & 19 & 17 & 7 & 1 & 2 & 8 & 2 & 2 & 0 & 8 \\
\hline
\end{tabular}


Journal of Applied Business Administration Vol 1, No 1, Maret 2017, hlm. 122-138

\begin{tabular}{|c|c|c|c|c|c|c|c|c|c|c|}
\hline $\mathrm{Jml}(\mathrm{R})$ & 0 & 0 & 0 & 0 & 0 & 0 & 0 & 0 & 0 & 0 \\
\hline $\mathrm{Jml}(\mathrm{Q})$ & 0 & 0 & 0 & 0 & 0 & 0 & 0 & 0 & 0 & 0 \\
\hline $\mathrm{Jml}(\mathrm{I})$ & 0 & 6 & 4 & 8 & 4 & 0 & 1 & 1 & 29 & 19 \\
\hline \multirow{2}{*}{$\mathrm{Ttl}$} & 30 & 30 & 30 & 30 & 30 & 30 & 30 & 30 & 30 & 30 \\
& $(100 \%)$ & $(100 \%)$ & $(100 \%)$ & $(100 \%)$ & $(100 \%)$ & $(100 \%)$ & $(100 \%)$ & $(100 \%)$ & $(100 \%)$ & $(100 \%)$ \\
\hline
\end{tabular}

Sumber: Data Olahan, 2016

Keterangan:

P: kualitasproduk

$\mathrm{H}$ : harga

$\mathrm{J}$ : kualitas jasa

E: emosional

B: biaya

M: Must be

O: One dimensional

A: Attractive

Q: Questionable

I: Indifferent

$\mathrm{R}$ : Reverse

\section{Pemetaan Dimensi Kepuasan \\ Konsumen Kedalam Kuadran Kano}

Dalam melakukan pemetaan tiap dimensi

kepuasan konsumen, tentunya kita harus mengetahui kordinatnya $(\mathrm{X}, \mathrm{Y})$ dari tiap dimensi tersebut. Melalui model Kano, kepuasan menggunakan sepeda motor Yamaha Vixion di Kecamatan Bangkinang Kota, Kabupaten Kampar, Riau akan dipetakan berdasarkan perhitungan CS-Coefficient. CS-Coefficient dihitung dengan menggunakan persamaan sebagai berikut:

Tabel 9. Perhitungan CS Coefficient

\begin{tabular}{|c|c|c|c|c|c|c|c|}
\hline \multirow{2}{*}{$\begin{array}{c}\text { Dimensi Kepuasan } \\
\text { Konsumen }\end{array}$} & \multirow{2}{*}{$\mathbf{A}$} & \multirow{2}{*}{$\mathbf{M}$} & \multirow{2}{*}{$\mathbf{O}$} & \multirow{2}{*}{ I } & \multirow{2}{*}{$\begin{array}{c}\text { Kategori } \\
\text { Kano }\end{array}$} & \multirow{2}{*}{$\begin{array}{c}\mathrm{A}+\mathrm{O} \\
\mathrm{A}+\mathrm{O}+\mathrm{M}+\mathrm{I}\end{array}$} & \multirow{2}{*}{$\begin{array}{c}\mathrm{O}+\mathrm{M} \\
(\mathrm{A}+\mathrm{O}+\mathrm{M}+\mathrm{I} \times(-1)\end{array}$} \\
\hline & & & & & & & \\
\hline Kualitas Produk & 8 & 1 & 18 & 3 & $\mathrm{O}$ & 0,87 & $-0,63$ \\
\hline Harga & 3 & 17 & 4 & 6 & $M$ & 0,23 & $-0,70$ \\
\hline Kualitas Jasa & 17 & 6 & 5 & 2 & $\mathrm{~A}$ & 0,73 & $-0,37$ \\
\hline Emosional & 21 & 6 & 2 & 1 & $\mathrm{~A}$ & 0,77 & $-0,27$ \\
\hline Biaya & 1 & 1 & 4 & 24 & $\mathrm{I}$ & 0,17 & $-0,17$ \\
\hline
\end{tabular}

Sumber: Data Olahan, 2016

Keterangan:

A: Attractive

M: Must be

Dari data perhitungan CS coefficient pada tabel 9, selanjutnya memetakan tiap atribut ke dalam kuadrat Kano dengan ketentuan sebagai berikut :

1. Kategori Indifferent mempunyai nilai koefisien yang tinggi pada kepuasan dan ketidakpuasan.

2. Kategori One Dimensional mempunyai nilai koefisien ketidakpuasan tinggi dan nilai kepuasan rendah.

3. Kategori Atractive mempunyai nilai
Koefisien kepuasan:

$$
\frac{\mathrm{A}+\mathrm{O}}{\mathrm{A}+\mathrm{O}+\mathrm{M}+\mathrm{I}}
$$

Koefisien ketidakpuasan:

$$
\frac{\mathrm{O}+\mathrm{M}}{(\mathrm{A}+\mathrm{O}+\mathrm{M}+\mathrm{I}) \times(-1)}
$$

Data hasil perhitungannya dapat dilihat pada tabel V. 4 berikut. 
Suryalena \& Sri, Analisis Kepuasan Konsumer

menggunakan model Kano. Kuadran Kano berikut. tersebut sebagaimana tampak pada gambar 5

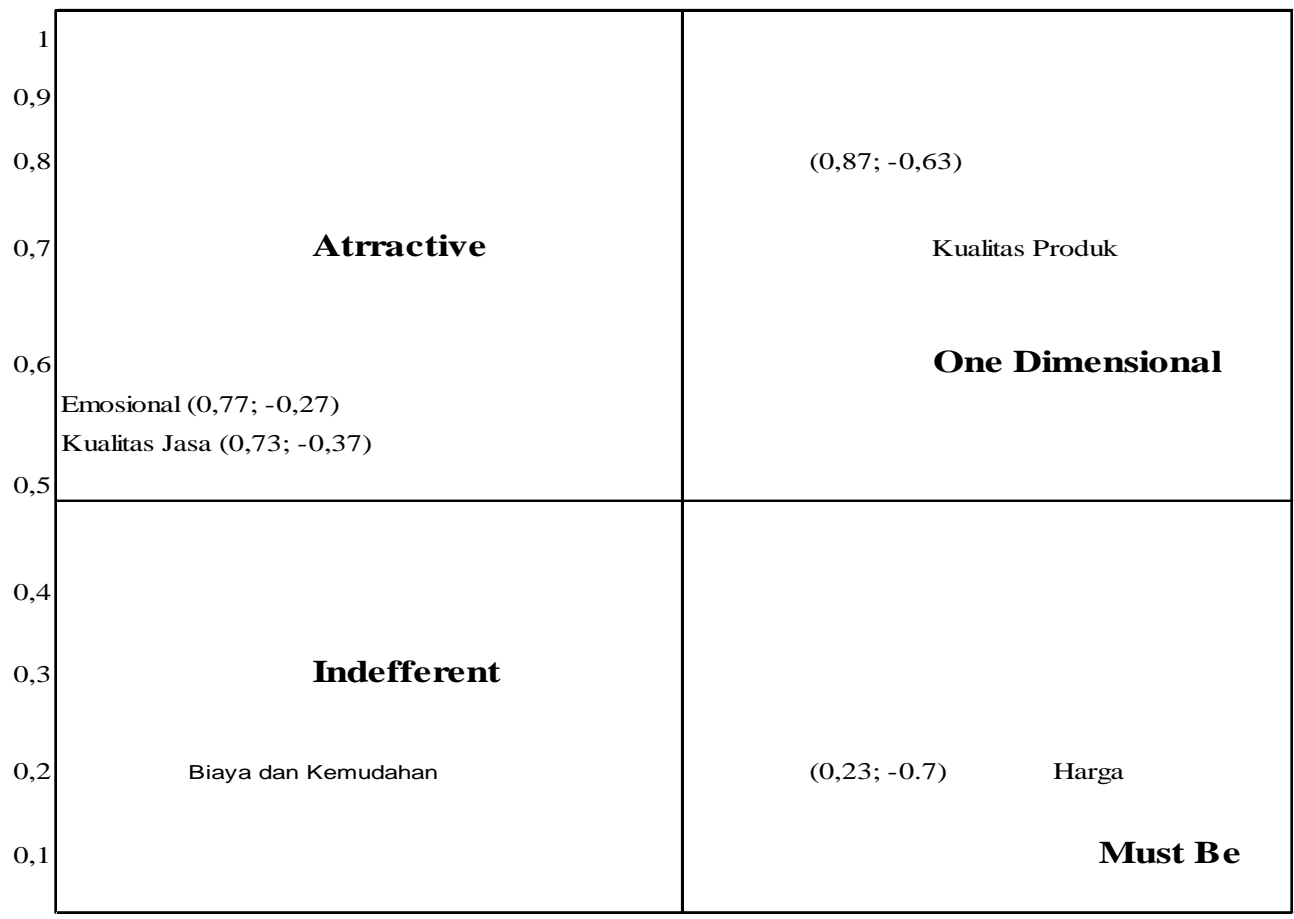

Gambar 5. Diagram Kuadran Kano

Sumber: Data Olahan, 2016

Berdasarkan diagram Kuadran Kano bahwa 5 dimensi kepuasan konsumen menggunakan sepeda motor Yamaha Vixion di Kecamatan Bangkinang Kota, Kabupaten Kampar, Riau melalui perhitungan $C S$ Coefficient, maka dibangunlah suatu Kuadran Kano, dimana terdiri dari 4 bagian kuadran yaitu must be, one dimensional, attractive, dan indifferent. Berikut penjelasan masing-masing dimensi kepuasan konsumen berdasarkan posisi nya pada kuadran Kano.

\section{Must be (dimensi harga)}

Kategori must be adalah dimensi kepuasan konsumen dimana konsumen menjadi tidak puas dengan kinerja dimensi kepuasan konsumen yang rendah namun kepuasan konsumen tidak akan meningkat diatas normal walaupun kinerja dimensi kepuasan konsumen ini tinggi.

Ini bermakna bahwa penetapan harga yang rendah menyebabkan konsumen tidak puas, namun apabila penetapan harga ditingkatkan tidak pula dapat menyebabkan kepuasan konsumen meningkat. Hal ini barangkali terkait dengan pemahaman umum pada bisniss bahwa harga merupakan tolok ukur kualitas suatu produk, sehingga jika harga sepeda motor Yamaha Vixion ditetapkan rendah mengakibatkan konsumen menjadi tidak puas. Penetapan harga maksudnya adalah harga pembelian sepeda motor Yamaha Vixion dan juga harga spare part dan perawatan sepeda motor.

\section{One dimensional (dimensi kualitas produk)}

Kategori one dimensional adalah dimensi kepuasan konsumen yang memiliki fungsi linear dengan kinerja dimensi kepuasan konsumen Maknanya, semakin baik kinerja atau kualitas produk sepeda motor Yamaha Vixion, maka semakin tinggi tingkat kepuasan konsumen dalam menggunakan sepeda motor $\backslash$ Yamaha Vixion di 
Kecamatan Bangkinang Kota, Kabupaten Kampar, Riau. Ini terjadi karena konsumen menilai bahwa produk sepeda motor adalah produk yang digunakan untuk jangka panjang, sehingga kualitas produk memiliki fungsi yang linear dengan kepuasan mereka

\section{Attractive (dimensi kualitas jasa dan emosional)}

Dapat digambarkan sebagai dimensi senang atau kejutan. Dimensi ini mencapai kepuasan ketika tercapai sepenuhnya, tetapi tidak menyebabkan ketidakpuasan ketika tidak terpenuhi.Maknanya kualitas jasa, baik pada saat proses pembelian, service dan perbaikan maupun penanganan keluhan konsumen sangat mengejutkan atau menyenangkan hati konsumen. Karena dianggap sebagai value added atau bonus, sehingga rendahnya pelaksanaan kualitas jasa tidak menyebabkan konsumen tidak puas. Hal ini terjadi dikarenakan konsumen merasa produk sepeda motor Yama Vixion adalah produk dengan dominasi barangnya dan jasa hanya merupakan penunjang.

Demikian halnya dengan dimensi emosional. Konsumen saat ini adalah konsumen yang semakin ingin dimanjakan. Sehingga, ketika sepeda motor Yamaha Vixion dapat meningkatkan rasa percaya diri atau harga diri juga nilai sosial pengendara maupun penumpang, perasaan konsumen menjadi tersentuh (touch to heart), sehingga konsumen merasa puas. Namun, rendahnya pelaksanaan dimensi emosional jasa tidak menyebabkan konsumen tidak puas.

\section{Indifferent (dimensi biaya atau kemudahan)}

Kategori indifferent adalah dimensi kepuasan konsumen dimana kinerjanya tidak menghasilkan kepuasan dan ketidakpuasan konsumen. Maknanya, pelaksanaan biaya atau kemudahan kepada konsumen dalam hal bengkel resmi Yamaha mudah ditemui serta biaya service dan perawatan sepeda motor Yamaha Vixion yang terjangkau tidak menghasilkan kepuasan maupun ketidakpuasan konsumen. Hal i ni terjadi karena konsumen sepeda motor Yamaha Vixion yang tergabung dalam komunitas konsumen Yamaha Vixion Club Chapter Bangkinang saling sharing seputar service dan perawatan sepeda motor Vixion mereka dan keberadaan bengkel resmi Yamaha juga bukan suatu hal penting bagi mereka, sehingga hal tersebut tidak menghasilkan kepuasan maupun ketidakpuasan konsumen.

\section{SIMPULAN DAN SARAN Simpulan}

Berdasarkan hasil penelitian yang telah dibahas pada bab sebelumnya, maka dapat disimpulkan terkait kepuasan konsumen dalam menggunakan sepeda motor Yamaha Vixion di Kecamatan Bangkinang Kota, Kabupaten Kampar, Riau yang diukur berdasarkan 5 dimensi, yaitu :

- Dimensi kualitas produk adalah dimensi yang memiliki fungsi linear dengan kinerja dimensi kepuasan konsumen. Semakin tinggi pelaksanaan kualitas produk menyebabkan konsumen pengguna sepeda motor Yamaha Vixion di Kecamatan Bangkinang Kota, Kabupaten Kampar, Riau semakin terpuaskan.

- Selanjutnya, dimensi harga adalah konsumen menjadi tidak puas dengan penetapan harga yang rendah, namun apabila penetapan harga ditingkatkan tidak pula dapat menyebabkan kepuasan konsumen meningkat.

- Dimensi kualitas jasa dan emosional adalah dimensi kepuasan konsumen kejutan. Artinya, kualitas jasa, baik pada saat proses pembelian, service dan perbaikan maupun penanganan keluhan konsumen sangat mengejutkan atau menyenangkan hati konsumen. Karena dianggap sebagai value added atau bonus, sehingga rendahnya pelaksanaan kualitas jasa tidak menyebabkan konsumen tidak puas. Demikian halnya dengan dimensi emosional.

- Dimensi biaya atau kemudahan kepada konsumen dalam hal bengkel resmi Yamaha mudah ditemui serta biaya service dan perawatan sepeda motor Yamaha Vixion yang terjangkau tidak 
Suryalena \& Sri, Analisis Kepuasan Konsumer

menghasilkan kepuasan maupun ketidakpuasan konsumen.

\section{Saran}

Berdasarkan hasil penelitian, maka bagi setiap business terutama business yang terlibat dalam pemuasan konsumen pengguna sepeda motor Yamaha Vixion, seperti producer, distributor resmi dan bengkel resmi bahwa kepuasan konsumen adalah hal yang sangat vital untuk keberlangsungan business. Diharapkan producer terus memfokuskan sumber daya perusahaan untuk meningkatkan kualitas produk sepeda motor Yamaha Vixion karena dinilai konsumen sebagai dimensi kepuasan konsumen yang memiliki fungsi linear. Artinya, semakin tinggi kualitas produk, semakin tinggi pula kepuasan konsumen. Dan perusahaan dapat mengabaikan dimensi biaya dan kemudahan karena konsumen menilai dimensi ini tidak dapat membangun kepuasan maupun ketidakpuasan konsumen.

\section{DAFTAR PUSTAKA}

Cravens, David W. (2000). Strategic Marketing. USA: Irwin McGraw-Hill.

Fajar, Andrianus Dwi. (2011). Desain Prosedur Penilaian Kepuasan Pelanggan Dalam Rangka Implementasi ISO 9001: 2008 dengan Menggunakan Metode SERVQUAL Dan Model Kano Di Sebuah Perusahaan Jasa Transportasi Alat Berat. ITB: Bandung. Skripsi tidak Dipublikasikan

Irawan, Handi. (2007). Kepuasan Pelanggan. Jakarta: PT. Elek Media Koputindo

Kotler, Philip. (2002). Manajemen Pemasaran, Jilid 2, Edisi ke 10 atau Milenium, Jakarta: Prenhallindo

Mc Alexander; Schouten, James H. dan Koeing Harold. (2002). Building Brand Community. Journal of Marketing, Vol. 66.

Ohmae, Kenichi. (1990). The Mind of the Strategist:The Art of Japanese Business. USA: McGraw-Hill.

Porter, Michael. (1980). Competitive Strategy: Techniques for Analyzing Industries and Competitors. Read more: http://www.referenceforbusiness.com/man agement/Or-Pr/Porter-s-5-ForcesModel.html\#ixzz3q69wgVYG
Riyanto, Y. (2001). Metode Penelitian, Surabaya: SIC

Sembiring, Alfiusta (2015). Analisis Kepuasan Konsumen Menggunakan Model Kano (Kasus pada Lembaga Bimbingan Belajar Smart Ganesha Cabang Panam, Pekanbaru). Pekanbaru: Universitas Riau

Sugiyono. (2010). Metode Penelitian Bisnis. Bandung: CV. Alfabeta

Tjiptono, Fandy. (2002). Strategi Pemasaran, Yogyakarta: Andi.

Wibisiono, Dermawan. (2003). Riset Bisnis: Panduan bagi Praktisi dan Akademisi. Jakarta: PT. Gramedia Pustaka Utama.

Yuswohady. (2008). CROWD: Marketing Becomes Horizontal. Jakarta: PT. Gramedia Pustaka Utama. 